\title{
Dose-response study of nebulised nedocromil sodium in exercise induced asthma
}

\author{
M K ALBAZZAZ, M G NEALE, K R PATEL \\ From the Department of Respiratory Medicine, Western Infirmary, Glasgow, and the Department of Clinical \\ Pharmacology, Fisons PLC, Loughborough
}

ABSTRACT Ten patients with exercise induced asthma, in whom inhaled nedocromil sodium 4 mg by $\vec{P}$ metered dose inhaler attenuated the exercise fall in forced expiratory volume in one second $\left(\mathrm{FEV}_{1}\right)$ by at least $40 \%$, participated in a double blind dose response study to compare the protective effect ob nedocromil sodium given 15 minutes before exercise challenge via a nebuliser (Wright) in concentrations of $0.5,5,10$, and $20 \mathrm{mg} / \mathrm{ml}$ with that of placebo (saline). Response was assessed as the maximum fall in $\mathrm{FEV}_{1}$ after the patient had run on a treadmill for six to eight minutes. Plasmaे concentrations of nedocromil sodium were measured at the time of challenge. After exercise challengen the mean (SEM) maximum percentage falls in $\mathrm{FEV}_{1}$ were $30 \cdot 3(1 \cdot 6)$ for the control run and $28 \cdot 0(4 \cdot 1)$ after placebo. The percentage fall was attenuated by pretreatment with all concentrations op nedocromil sodium to $12 \cdot 8(2 \cdot 8), 11 \cdot 2(2 \cdot 1), 12 \cdot 8(2 \cdot 1)$, and $14 \cdot 1(3 \cdot 5)$ for the $0 \cdot 5,5,10$, and $20 \mathrm{mg} / \mathrm{mb}$ concentrations respectively $(\mathrm{p}<0.001)$. There were no significant differences between the differen nedocromil concentrations. Mean plasma concentrations of nedocromil were proportional to dose Thus concentrations of nebulised nedocromil sodium that ranged from 0.5 to $20 \mathrm{mg} / \mathrm{ml}$ gave a similan degree of protection (50-60\%) against exercise induced asthma. This appears to be the maximump protection that can be achieved with nedocromil sodium and is similar to the protection obtained with $4 \mathrm{mg}$ nedocromil administered by metered dose aerosol.

\section{Introduction}

Nedocromil sodium is the salt of a pyranoquinoline dicarboxylic acid that has been developed for the treatment of reversible obstructive airways disease. ${ }^{12}$ It is thought to reduce inflammation. ${ }^{2}$ In vitro it prevents the release of histamine and other mediators from lung mast cells ${ }^{3}$ and in asthmatic patients inhalation of $4 \mathrm{mg}$ nedocromil sodium is effective in blocking allergen induced bronchoconstriction for at least three ${ }^{4}$ and possibly up to six hours. ${ }^{5}$ The drug also offers partial protection against bronchoconstriction due to sulphur dioxide, ${ }^{6}$ fog, ${ }^{7}$ cold air, ${ }^{8}$ adenosine, ${ }^{9}$ and exercise. ${ }^{10}$ In clinical trials $4 \mathrm{mg}$ inhaled nedocromil sodium was more effective than placebo in controlling symptoms and improving lung function in adult asthmatic patients with both twice and four times daily dosing. ${ }^{11-14}$ Despite numerous studies with various

Address for reprint requests: Dr K R Patel, Department of Respiratory Medicine, Western Infirmary, Glasgow G11 6NT.

Accepted 15 July 1989 bronchial provocation tests comparatively little is known of the dose-response characteristics of nedocromil sodium.

The aim of the present study was to examine the dose-response characteristics of nedocromil sodiumb over a range of concentrations in patients with exercise induced asthma, a nebulised solution being used to allow greater flexibility in dosing. Plasma concentra tions of the drug were measured as a check or absorbed dose.

\section{Methods}

Twelve men with extrinsic asthma were screened and 10 of these, aged 17-54 (mean 37, SEM 4) years, were enrolled. The selected patients had previously beeff shown to have exercise induced asthma with a fall in $\mathrm{FEV}_{1}$ of more than $20 \%$ after exercise challenge. They also had at least $40 \%$ protection against the fals following treatment with nedocromil sodium aerosot (4 mg). Patients taking sodium cromoglycate of inhaled bronchodilators discontinued these for $2 \mathbb{R}$ hours and 12 hours respectively before each exercise 
test. Inhaled corticosteroids were continued during the study. None of the patients was taking oral steroids, theophylline preparations, or antihistamines. Informed consent was obtained and the study was approved by the hospital ethics committee.

FEV , was measured with a dry wedge spirometer (Vitalograph, Buckingham) and the best of three attempts was recorded for analysis. The exercise test consisted of steady state running on an inclined treadmill for six to eight minutes with a submaximal work load, adjusted to produce over $80 \%$ of the maximum predicted heart rate. The temperature on the study days was $20-22^{\circ} \mathrm{C}$ and the relative humidity $40-60 \%$. The same treadmill setting and exercise duration were used for each test in a given patient. The series of six challenge tests on each patient was completed within 20 days.

The effect of two puffs $(4 \mathrm{mg})$ of nedocromil sodium from a standard metered dose inhaler (Tilade) on exercise challenge was tested during the first visit. On the subsequent five visits the patient received each of four concentrations of nedocromil $(0.5,5,10$, and $20 \mathrm{mg} / \mathrm{ml}$ ) and placebo by nebuliser in a double blind randomised fashion. The solutions were delivered via a Wright nebuliser driven by compressed air at a flow rate of $9 \mathrm{l} / \mathrm{min}\left(18 \mathrm{lb} / \mathrm{in}^{2}, 124 \mathrm{kPa}\right)$. Dosing started 20 minutes before exercise challenge. All inhalations were carried out with the patient breathing tidally for five minutes, during which time about $1 \mathrm{ml}$ of solution was nebulised. The estimated amounts of drug nebulised were $0 \cdot 5,5,10$, and $20 \mathrm{mg}$. FEV 1 was recorded before dosing and 5 and 15 minutes after the end of dosing (that is, immediately before exercise) and then one, two, five, 10, 15, and 30 minutes after exercise. The $\mathrm{FEV}_{1}$ response to exercise was expressed as the maximal fall in $\mathrm{FEV}_{1}$ from the post-drug baseline. The degree of protection was calculated as:

$\frac{\text { (Maximum control fall }- \text { maximum test fall) }}{\text { (Maximum control fall) }} \times 100 \%$

Venous blood samples $(5 \mathrm{ml})$ were taken from the antecubital vein immediately before each exercise test (that is, 20 minutes after the start of nebulisation). The blood was centrifuged immediately and the plasma separated and stored at $-20^{\circ} \mathrm{C}$ until analysed. Plasma concentrations of nedocromil sodium were deter- mined by a sensitive radioimmunoassay, ${ }^{15}$ which had a suitable range and linearity for the concentrations measured in this study.

\section{ANALYSIS}

Responses to each drug concentration were compared by analysis of variance with repeated measures and paired Student's $t$ test. A p value of 0.05 was accepted as significant.

\section{Results}

There were no significant differences between mean baseline $\mathrm{FEV}_{1}$ values before and after any of the treatments (table 1). The work load and maximum heart rate achieved by each subject in the control test are given in table 2. After exercise challenge the mean (SEM) maximum percentage falls in $\mathrm{FEV}_{1}$ were similar for control (30.3 (1.6)) and placebo (28.0 (4.1)); all active treatments showed much smaller percentage falls in $\mathrm{FEV}_{1}$, with values of 10.6 (2.6), $12 \cdot 8(2 \cdot 8), 11 \cdot 2$ $(2 \cdot 1), 12 \cdot 8(2 \cdot 1)$, and $14 \cdot 1(3 \cdot 5)$ for the $4 \mathrm{mg}$ inhaler dose and the $0.5,5,10$, and $20 \mathrm{mg} / \mathrm{ml}$ nebulised solution (table 2). The exercise induced fall in $\mathrm{FEV}_{1}$ was inhibited by all concentrations of nedocromil sodium; the maximum falls were significantly different from those after placebo ( $p<0.001)$. There were no significant differences between active treatments.

The time course of change in $\mathrm{FEV}_{1}$ is shown in the figure. Significant differences between placebo and active treatments were found at all time points after exercise except the first. There were no significant differences between active treatments. The recovery in $\mathrm{FEV}_{1}$ was quicker with active treatments than with placebo. Thirty minutes after exercise the FEV had returned to baseline value after nedocromil whereas with placebo it was still more than $15 \%$ below the prechallenge value (figure).

The protective effect of nedocromil sodium $(4 \mathrm{mg})$ from a metered dose inhaler was similar to that produced by all the nebulised concentrations and was more than $50 \%$ in all cases. The percentage protection was 8.9(12.0), 58.8 (8.9), 65.0 (6.3), 58.8 (7.7) and 56.7 $(9.0)$ for placebo and the $0.5,5,10$, and $20 \mathrm{mg} / \mathrm{ml}$ nebulised solution.

Nebulised salbutamol was required after challenge

Table 1 Mean (SEM) baseline values of FEV $(l)$ before and after administration of placebo and nedocromil sodium in 10 patients

\begin{tabular}{|c|c|c|c|c|c|c|}
\hline & \multirow[b]{2}{*}{ Placebo } & \multirow{2}{*}{$\begin{array}{l}4 \mathrm{mg} \text { nedocromil metered } \\
\text { dose inhaler }\end{array}$} & \multicolumn{4}{|c|}{ Nebulised nedocromil concentration ( $\mathrm{mg} / \mathrm{ml})$} \\
\hline & & & 0.5 & 5 & 10 & 20 \\
\hline $\begin{array}{l}\text { Before } \\
\text { After }\end{array}$ & $\begin{array}{l}3.38(0.31) \\
3.33(0.35)\end{array}$ & $\begin{array}{l}3.34(0.35) \\
3.40(0.36)\end{array}$ & $\begin{array}{l}3.31(0.33) \\
3.28(0.35)\end{array}$ & $\begin{array}{l}3.26(0.34) \\
3.26(0.35)\end{array}$ & $\begin{array}{l}3.21(0.33) \\
3.26(0.35)\end{array}$ & $\begin{array}{l}3.32(0.37) \\
3.31(0.39)\end{array}$ \\
\hline
\end{tabular}


Table 2 Age, workload and heart rate, and maximal percentage fall in FEV, after exercise challenge after placebo and after $\overrightarrow{\overline{\vec{V}}}$ nedocromil sodium nebulised at different concentrations and from a pressurised inhaler in 10 patients

\begin{tabular}{|c|c|c|c|c|c|c|c|c|c|c|}
\hline \multirow{2}{*}{$\begin{array}{l}\text { Patient } \\
\text { no }\end{array}$} & \multirow{2}{*}{$\begin{array}{l}\text { Age } \\
(y)\end{array}$} & \multirow{2}{*}{$\begin{array}{l}\text { Work load } \\
(\mathrm{kpm} / \mathrm{min})\end{array}$} & \multirow{2}{*}{$\begin{array}{l}\text { Heart rate } \\
\text { (beats } / \mathrm{min})^{*}\end{array}$} & \multirow[b]{2}{*}{ Control } & \multirow[b]{2}{*}{ Placebo } & \multicolumn{4}{|c|}{ Nebulised nedocromil concentration ( $\mathrm{mg} / \mathrm{ml})$} & \multirow{2}{*}{$\begin{array}{l}4 \text { mg nedocrom } \\
\text { by metered dos } \\
\text { inhaler }\end{array}$} \\
\hline & & & & & & $0 \cdot 5$ & 5 & 10 & 20 & \\
\hline $\begin{array}{r}1 \\
2 \\
3 \\
4 \\
5 \\
6 \\
7 \\
8 \\
9 \\
10\end{array}$ & $\begin{array}{l}49 \\
28 \\
35 \\
49 \\
36 \\
24 \\
17 \\
54 \\
43 \\
35\end{array}$ & $\begin{array}{r}1316 \\
2038 \\
1750 \\
1371 \\
1579 \\
1603 \\
1457 \\
967 \\
1738 \\
1714\end{array}$ & $\begin{array}{l}150(178) \\
167(192) \\
162(187) \\
150(178) \\
170(187) \\
170(194) \\
194(199) \\
164(175) \\
166(182) \\
168(187)\end{array}$ & $\begin{array}{l}28 \cdot 4 \\
35 \cdot 8 \\
27 \cdot 0 \\
34 \cdot 9 \\
37 \cdot 9 \\
21 \cdot 5 \\
30 \cdot 4 \\
28 \cdot 8 \\
26 \cdot 2 \\
31 \cdot 4\end{array}$ & $\begin{array}{r}6 \cdot 1 \\
27 \cdot 9 \\
27 \cdot 1 \\
38 \cdot 4 \\
27 \cdot 9 \\
15 \cdot 9 \\
50 \cdot 3 \\
18 \cdot 7 \\
26 \cdot 8 \\
41 \cdot 2\end{array}$ & $\begin{array}{r}0 \cdot 0 \\
12 \cdot 5 \\
22 \cdot 8 \\
27 \cdot 4 \\
8 \cdot 4 \\
3 \cdot 2 \\
8 \cdot 6 \\
8 \cdot 3 \\
19 \cdot 3 \\
17 \cdot 1\end{array}$ & $\begin{array}{r}2 \cdot 3 \\
14 \cdot 9 \\
11 \cdot 2 \\
18 \cdot 3 \\
18 \cdot 1 \\
4 \cdot 6 \\
7 \cdot 8 \\
1 \cdot 8 \\
16 \cdot 9 \\
16 \cdot 0\end{array}$ & $\begin{array}{r}18 \cdot 2 \\
11 \cdot 8 \\
4 \cdot 7 \\
18 \cdot 5 \\
20 \cdot 1 \\
15 \cdot 8 \\
8.9 \\
0.0 \\
18.9 \\
10.9\end{array}$ & $\begin{array}{r}6 \cdot 4 \\
34 \cdot 9 \\
2 \cdot 6 \\
22 \cdot 9 \\
5 \cdot 8 \\
5 \cdot 8 \\
9 \cdot 4 \\
9 \cdot 0 \\
15 \cdot 6 \\
29 \cdot 0\end{array}$ & $\begin{array}{r}1 \cdot 2 \\
1 \cdot 0 \\
7 \cdot 7 \\
19 \cdot 3 \\
24 \cdot 8 \\
1 \cdot 8 \\
17 \cdot 0 \\
7 \cdot 5 \\
10 \cdot 1 \\
16 \cdot 0\end{array}$ \\
\hline Mean & 37 & 1553 & $166(186)$ & $30 \cdot 3$ & $28 \cdot 0$ & $12 \cdot 8$ & $11 \cdot 2$ & $12 \cdot 8$ & $14 \cdot 1$ & $10 \cdot 6$ \\
\hline SEM & 4 & 93 & $14(3)$ & $1 \cdot 6$ & $4 \cdot 1$ & $2 \cdot 8$ & $2 \cdot 1$ & $2 \cdot 1$ & $3 \cdot 5$ & $2 \cdot 6$ \\
\hline
\end{tabular}

*Age-predicted maximum heart rate in parentheses and calculated by the formula $210-0.65 \times$ age $(y)$. $\mathrm{kmp}-$ kilopond meter.

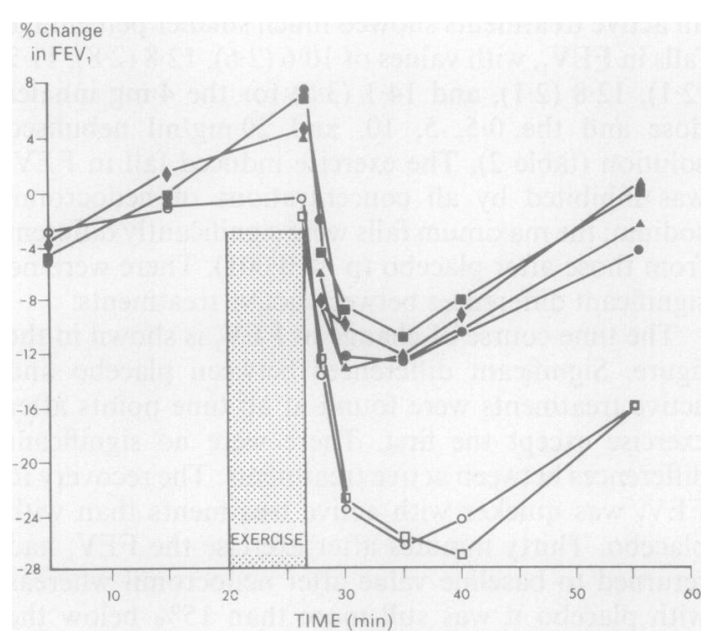

Fig Time course of changes in FEV, with placebo and different nebulised concentrations of nedocromil sodium after exercise challenge. All post-exercise nedocromil treatments gave results significantly different $(p<0.001)$ from those after placebo except at 26 minutes - that is, immediately after exercise. Nedocromil sodium concentrations: $0.05 \%$; $\square 0.5 \% ; \diamond 1 \% ; \Delta 2 \%$. $\bigcirc$ Placebo; $\square$ control.

by all subjects after the control test; by five after placebo; by one after 0.5 and $20 \mathrm{mg} / \mathrm{ml}$ nedocromil; by one after $0.5,5$, and $20 \mathrm{mg} / \mathrm{ml}$; and by another after $10 \mathrm{mg} / \mathrm{ml}$ nedocromil.

Individual patients showed some variability in response with the occasional unusual result. Such atypical results were not, however, due to variable absorption as the plasma concentrations of nedocromil sodium were consistent and proportional to the dose given. The mean (SEM) plasma concentrations of nedocromil sodium $(\mathrm{ng} / \mathrm{ml})$ immediately before exercise challenge were: $0.5 \mathrm{mg} / \mathrm{ml}$-not detectable; $5 \mathrm{mg} / \mathrm{ml}-2.1(0.6) ; 10 \mathrm{mg} / \mathrm{ml}-5.9(1.4) ; 20 \mathrm{mg} /$ $\mathrm{ml}-12 \cdot 8(2 \cdot 1)$; and $4 \mathrm{mg}$ aerosol-2.4 (0.6).

\section{Discussion}

This study shows that nebulised nedocromil sodium administered 15 minutes before exercise challenge too susceptible patients in concentrations from $0.5 \mathrm{mg} / \mathrm{ml}$ to $20 \mathrm{mg} / \mathrm{ml}$ is effective in attenuating the fall in FEV with no significant difference in the inhibitory effecs between the four concentrations. Protection wa $\bar{s}$ about $50 \%$, which is similar to that afforded by $4 \mathrm{mg}$ nedocromil from a metered dose inhaler. Althoug there was no difference between the protection affor $\overline{\overline{0}}$ ded by the different nebuliser concentrations, plasm $\$$ concentrations were related to nebuliser concentratio $\bar{P}$ and hence to dose. In this respect $4 \mathrm{mg}$ nedocrom $\mathrm{m}$. from the metered dose inhaler produced plasmet concentrations similar to the $5 \mathrm{mg} / \mathrm{ml}$ nebuliser cone centration, suggesting that the dose absorbed is similar. Previous studies have shown a protective effect of nedocromil sodium from a metered dosê. inhaler in exercise challenge. ${ }^{1016}$

In this study the response to nedocromil was not dose dependent over the range of doses studied. Thig contrasts with earlier observations with sodium cromoglycate in exercise challenge. ${ }^{17} 18$ The difference. may reflect the fact that nedocromil sodium is more potent than sodium cromoglycate, as shown in some in vitro ${ }^{19}$ and in vivo models, ${ }^{2021}$ so that all doses lie near the top of the dose-response curve. Use of lowed concentrations 15 minutes before challenge would probably result in a dose related response. Duration effect might be expected to vary with dose; this is unde investigation.

Exercise induced bronchoconstriction is a welt recognised phenomenon in asthma and, although the exact mechanism of its pathogenesis is not clear, provides a relatively safe method for assessing thi effect of various drugs. The coefficient of variation was calculated to vary from $12 \%$ to $16 \%$ in a recent study in our department, ${ }^{22}$ though intrasubject variation håg been reported to be as high as $25 \%{ }^{23}$ Release of masi 
cell associated mediators, such as high molecular weight neutrophil chemotactic factor ${ }^{24}$ and histamine ${ }^{25}$ during exercise has been reported. Sodium cromoglycate prevents both the development of exercise asthma and the accompanying mediator release. ${ }^{25}$ This is thought to reflect, at least in part, its action as a mast cell stabiliser. Animal studies have identified a heterogeneity of mast cells with connective tissue and mucosal subtypes. ${ }^{26}$ Nedocromil sodium stabilises both. ${ }^{3}$ This property may account for its ability to attenuate exercise asthma. The mechanisms of action of nedocromil sodium and sodium cromoglycate in the response to exercise challenge and in other models of asthma are not at present clear. There is, however, evidence that nedocromil sodium is more potent than sodium cromoglycate in some models ${ }^{2021}$; and the results from this study, even though no direct comparison was made, suggest that nedocromil sodium has a dose-response profile different from that of sodium cromoglycate in exercise challenge, which may be due to greater potency.

\section{References}

1 Cairns H, Cox D, Gould KJ, Ingall AH, Suschitzky JL. New antiallergic pyrano [3,2-g]quinoline-2, 8-dicarboxylic acids with potential for the topical treatment of asthma. J Med Chem 1985;28:1832-42.

2 Cairns H, Orr TSC. The development of a new agent for the treatment of inflammatory/allergic conditions. Int Arch Allergy Immunol 1987;82:513-7.

3 Wells E, Jackson CG, Harper ST, Mann J, Eady RP. Characterisation of primate bronchoalveolar mast cells. II. Inhibition of histamine, LTC4 and PGD2 release from primate bronchoalveolar mast cells and a comparison with rat peritoneal mast cells. $J$ Immunol 1986;137:3941-5.

4 Youngchaiyud P, Lee TB. Effect of nedocromil sodium on the immediate response to antigen challenge in asthmatic patients. Clin Allergy 1985;15:129-34.

5 Robuschi M, Simone P, Fasano W, Bianco S. The efficacy and duration of action of nedocromil sodium compared with placebo in bronchial antigen challenge. Eur $J$ Respir Dis 1986;69(suppl 147):289-91.

6 Dixon CMS, Fuller RW, Barnes PJ. Effect of nedocromil sodium on sulphur dioxide induced bronchoconstriction. Thorax 1987;42:462-5.

7 Robuschi M, Vaghi A, Simone P, Bianco S. Prevention of fog-induced bronchospasm by nedocromil sodium. Clin Allergy 1987;17:69-74.

8 Juniper EF, Kline PA, Morris MM, Hargreave FE. Airway constriction by isocapnic hyperventilation of cold, dry air: comparison of magnitude and duration of protection by nedocromil sodium and sodium cromoglycate. Clin Allergy 1987;17:523-8.

9 Altounyan REC, Lee TB, Rocchiccioli KMS, Shaw CL. A comparison of the inhibitory effect of nedocromil sodium and sodium cromoglycate on adenosine monophosphate-induced bronchoconstriction in atopic subjects. Eur J Respir Dis 1986;69(suppl 147):277-9.

10 Roberts JA, Thomson NC. Attenuation of exercise- induced asthma by pretreatment with nedocromil sodium and minocromil. Clin Allergy 1985;15:377-81.

11 Lal S, Malhotra S, Gribben D, Hodder D. Nedocromil sodium: a new drug for the management of bronchial asthma. Thorax 1984;39:809-12.

12 Fairfax AJ, Allbeson M. A double-blind group comparative trial of nedocromil sodium and placebo in the management of bronchial asthma. J Int Med Res 1988;16:216-24.

13 Van As A, Chick TW, Bodman SF, et al. A group comparative study of the safety and efficacy of nedocromil sodium (Tilade) in reversible airways disease: a preliminary report. Eur $J$ Respir Dis 1986;69(suppl 147):143-8.

14 Fyans PG, Chatterjee PC, Chatterjee SS. A trial comparing nedocromil sodium (Tilade) and placebo in the management of bronchial asthma. Clin Allergy 1986;16:505-11.

15 Gardner JJ, Preston JR, Gilbert CM, Wilkinson DJ, Lockley WJS, Brown K. A radioimmunoassay method for the determination of nedocromil sodium in plasma and urine. J Pharm Biomed Anal 1988;6:285-97.

16 Shaw RJ, Kay AB. Nedocromil, a mucosal and connective tissue mast cell stabilizer, inhibits exercise-induced asthma. Br J Dis Chest 1985;79:385-9.

17 Patel KR, Berkin KE, Kerr JW. Dose-response study of sodium cromoglycate in exercise-induced asthma. Thorax 1982;37:663-6.

18 Tullett WM, Tan KM, Wall RT, Patel KR. Doseresponse effect of sodium cromoglycate pressurised aerosol in exercise induced asthma. Thorax 1985;40: 41-4.

19 Pearce FL, Al-Laith M, Bosman L, et al. Effects of sodium cromoglycate and nedocromil sodium on histamine secretion from mast cells from various locations. Drugs 1989;37(suppl 1):37-43.

20 Rocchiccioli KMS, Riley PA. Clinical pharmacology of nedocromil sodium. Drugs 1989;37(suppl 1):123-6.

21 Richards R, Phillips GD, Holgate ST. Nedocromil sodium is more potent than sodium cromoglycate against AMP-induced bronchoconstriction in atopic asthmatic subjects. Clin Exp Allergy 1989;19:285-91.

22 Patel KR. Role of histamine in exercise-induced asthma. Clin Exp Allergy (in press).

23 Hartley JPR, Nogrady SG. Effect of inhaled antihistamine on exercise-induced asthma. Thorax 1980;35: 675-9.

24 Lee TH, Nagy L, Nagakura T, Walport MJ, Kay AB. Identification and partial characterisation of an exercised-induced neutrophil chemotactic factor in bronchial asthma. J Clin Invest 1982;69:889-99.

25 Lee TH, Brown MJ, Nagy L, Causon R, Walport MJ, Kay AB. Exercise induced release of histamine and neutrophil chemotactic factors in atopic asthmatics. $J$ Allergy Clin Immunol 1982;70:73-81.

26 Pearce FL, Befus AD, Bienenstock J. Mucosal mast cells: III. Effect of quercetin and other flavonoids on antigeninduced histamine secretion from rat intestinal mast cells. J Allergy Clin Immunol 1984;73:819-23.

27 Lewis RA, Nencia-Huerta JM, Lee CW, Austen KF. Mast cell dependent synthesis of lipid mediators of immediate hypersensitivity. In: Kay AB, Austen KF, Lichtenstein LM, eds. Asthma: physiology, immunopharmacology and treatment. London: Academic Press, 1978:63-83. 